\title{
Effectiveness of Gymnastic Fantasy Stories and Method of Development of Motor Musical Accompaniment Rough
}

\author{
Hidayatul Faizzah'1); Hermani Triredjeki²) Susi Tentrem³); Bambang Sarwono ${ }^{4)}$ \\ hidayatul.faizz@gmail.com
}

\begin{abstract}
Background: Physical activity by optimizing physical education in schools to improve the gross motor skills of children (Burns, 2017). Gymnastics fantasy deemed appropriate, interesting and enjoyable in accordance with the age of the child and the child's world kindergarten - a child who likes to imitate everything he sees (Aini, 2016). Gymnastics fantasy able to develop gross motor skills and social skills emotional child. This study aims to determine the effectiveness of methods gymnastic fantasy stories as well as musical accompaniment to the development of gross motor kindergarten children in group B.

Methods: This was a comparative study used pretest and posttest. The subjects were thirty children in group one and thirty children in groups of two. The object of research was a gross motor skills. Data collection techniques in this study was the observation. Data analysis technique used paired t-test and independent t-test. This study was conducted over three weeks to nine times with a population of 79 children with sampling technique sampling kuota

Results: The results used paired t-test showed Sig (2-tailed), namely that there were significant 0,001. Gymnastics fantasy stories and musical accompaniment to the development of gross motor kindergarten children in group B and the results of 0001, indicating the significance hypothesis testing more effective than the method of story accompaniment

Conclusion: The increase in the gross motor skills of kindergarten children can do with more teaching exploration stories and integrated gymnastic movements to the accompaniment of music
\end{abstract}

Keyword : Gymnastic Fantasy Stories; Musical Accompaniment

1,2) Poltekkes Kemenkes Semarang, Indonesia

Jl. Tirtoagung, Pedalangan, Banyumanik

Background. The motor development of children have some benefits that train flexibility and muscle coordination fingers and hands, spur the growth and development of physical / motor development of children, establish, build and strengthen the child's body by using the whole body to move and play, train the skill or dexterity of movement and thinking children, improve social development of children to play with peers (Sulastri, 2017).

Research conducted by Yenny (2017) regarding the description of the motor development of children aged 5-6 years who play games gadget showed that the whole subject has differences in motor development. For gross motor development, 6 subjects $(33 \%)$ are in compliance, 10 subjects $(56 \%)$ is quite appropriate, and 2 subjects (11\%) less in accordance with his age.

Optimization of physical activity in schools to improve the gross motor skills of children. Physical activity to optimize physical education in schools to improve the gross motor skills of children (Burns, 2017). Gymnastics fantasy deemed appropriate,

interesting and enjoyable in accordance with the age of the child and the child's world kindergarten - kindergarten: the world play also in accordance with the nature of the winning children imitate against anything he sees (Aini, 2016). Fantasy gymnastics are also able to develop gross motor skills and social skills emotional because doing gymnastics fantasy children can socialize with peers (Sari, 2016).

Methods. This research uses comparative research, by comparing the two samples are free or independent. The sample used independent of each other or in other words samples from two different groups. (Sugiyono 2016 137). The population in this study were 79 children in group $B$ at Kindergarten Pertiwi Podosoko, Podosoko RA, BA Mangunsari and Kindergarten Pertiwi Sawangan years 2018-2019. A sample of $n 1=$ $\mathrm{n} 2=16$ samples at a minimum, in this study, researchers using 30 samples in each - each group, so that $n 1=n 2=30$ samples so that it meets the minimum sample taken from four schools. 
The research used quota sampling was a technique for determining a sample of the population that has traits - traits tertetu until the number (quota) is desired (Sugiyono 2016, 63). Provide interventions performed 9 times in each group

\section{Result and Discussion.}

The results used paired t-test showed Sig (2-tailed) was $0.001<0.05$ so that means there was the effect of the intervention method gymnastics fantasy story of the gross motor skills of children kindergarten group $B$. There was the effect of the exercise intervention fantasy musical accompaniment to the gross motor skills of children kindergarten group B.

Test the hypothesis can be seen in the column t-test on idependent test t-test showed $0.001 \mathrm{Sig}<0.05$ then there are differences between the two groups with each group. Mean Difference shows the mean difference between group one and group two, from the analysis of mean difference was 2.100 for the positive values of the group (gymnastics fantasy story method) is higher than the group two (gymnastics fantasy musical accompaniment).

Gross motor skills of children is closely related to the motion, therefore, the development of motor skills of children can be seen clearly through the range of motion and the game is done. If the child many moves it will be more skilled, master, quick to react, agile in moving and able to control the motor (Sujiono et al 2016, 1.3 - 1.4).

Gymnastics fantasy story method to attract the attention and interest of the child to participate in activities, stories used can be recreational theme, the theme of animals, it is in accordance with the opinion Samsudin that the attractiveness of a theme can improve gross motor skills of children (Yusmarni, 2012).

Storytelling able to give the value of learning for the child as well as the growing interest in, creating a pleasant atmosphere, and stimulate the process of cognition, particularly the activity of imagination, as well as a means to learn and build relationships that are familiar (Izza, 2013).

Gymnastics fantasy children stories methods listen to the story while imagination to portray the character in the story, the children play a role while moving, Aida (2015) observed that the children's learning through storytelling while playing this role makes the child spirit in following the activities. Children do not feel bored because they feel you're playing. Playing is a child's world, so that in the conduct of the children feel happy and not much to complain. This is according to research Ning (2013) that children are more enthusiastic about using role-playing for children involved in the implementation of storytelling.

The music that was used to make children more excited and enthusiastic to participate in activities. Motion used is a light movement does not require a heavy child motion so your child comfortable and happy doing the movement. Despite the relaxed movement but all members of the body part moves to follow the music, in gymnastics penguins are circular movements of the body, bowing and balance movements. Children are more confident to follow the movement because the movement cheerful and imitate animals (Pujiastuti, 2017).

Jumiyati (2015) observed that the method was more interested in children's stories for children is easy to understand because the stories relating to daily life - today. Hajrah (2018) observed that the method of the students feel good story with storytelling accompanied by questions and answers about the story, and the stories relating to daily life the children are easier to understand the story and listened attentively. Amri (2017) observed that plays a role in accordance with a story helps children to imagine and interact with friends and the environment thus creating an atmosphere that is fun for children.

Munawaroh (2015) observes that the music that is used to make children feel more interested and more enthusiastic in following the activities. Simple movements with the music that will make children happy pitched better in imitating grakan. Children can also merimajinasi when melakuakn movements with musical accompaniment So that children are able to develop gross motor skills. Febrialismanto (2017) observed that mimic the activity would be more fun if it is associated with the surrounding environment.

Rahmawati (2018) observed that the activities of gymnastics with music have an impact on children becomes feel interested, pleased with the event, there is an increased achievement in learning, improving motor skills and physical activity becomes better, fitness and health for the better, so that the overall tesebut point affects the child's motivation to follow the activities. 
Gymnastics fantasy methods of the story can be done indoors or outdoors, when indoors then dilakuakan utilization of space to explore the rest of the room with the child playing the role fit the character is told, role play around the room so that the child will be more mobile and free to move in accordance with the liveliness and creativity of each - each child. Gymnastics fantasy children's story method will move freely, play a role as a character who is told by example by teachers, children playing, move around or explore the room so that children are not only engaged at one point, gymnastics fantasy musical accompaniment while children also move freely while exemplified by teachers but children tend to only move at one point did not like the gymnastics fantasy story method. Unlike the case with musical accompaniment fantasy gymnastics movements are more likely the child was at one point so that the child does not explore the whole room.

Conclusion and Suggestions. Gross motor skills before being granted gymnastics fantasy musical accompaniment the second group showed that 9 children $(30 \%)$ with the category growing very well (BSB), 19 children $(63 \%)$ with the category growing expectations $(\mathrm{BSH})$, and 2 children $(7 \%)$ with categories ranging evolve (MB). Gross motor skills after being given gymnastics fantasy musical accompaniment on two groups showed that 18 children $(60 \%)$ with a very well developed category (BSB), and 12 children (40\%) with the category growing expectations (BSH).

Gross motor skills of children before being given a gymnastics fantasy method of story that 18 children $(60 \%)$ with the category growing very well (BSB), 10 children $(33 \%)$ with the category growing expectations (BSH), and there are 2 children (7\%) with category began to flourish. Gross motor skills of children after being given gymnastics fantasy story method that is 27 children (90\%) with a very well developed category (BSB), and 3 children $(10 \%)$ with the category growing expectations (BSH).

Gymnastics fantasy story method effect on gross motor development of children in group $\mathrm{B}$ at Kindergarten Pertiwi and RA Podosoko Podosoko and gymnastics fantasy musical accompaniment affect gross motor development of children in group $B$ at Kindergarten Pertiwi Sawangan and BA Mangunsari. The increase in the gross motor skills of kindergarten children can do with more teaching exploration stories and integrated gymnastic movements to the accompaniment of music.

Acknowledgements. Thanks to the researchers say to all those who have helped in completing this research.

\section{References}

Aida, et al. Implementation Method to Improve Ability Role Playing Catch On Early Childhood Education. Journal of Psychology Indonesia. 2015

Aini, et al. Effect of Gymnastics Fantasy Against Child Rough Motor Ability Group A. PG ECD Faculty of Education, State University of Surabaya. 2016.

Amri NA. Influence of Role Playing Against Method Capability Communication (Expressive Language) Kids Nursery Nursery Raudhatul Athfal Alauddin Makassar. LEARNERS: Journal of Science Education, Teaching, and Learning. 2017

Burns RD, et al. School Physical Activity Programming and Gross Motor Skills in Childen. 2017. Am J Health Behav 2017.41 (5): 591-598

Febrialismanto. Overview of Motor Rough Childhood 4-5 Years in Taman Kanak Kanak Bangkinang District of Kampar regency, Riau Province. Journal of Enchantment Elementary. 2017

Hajrah. Storytelling Method Development In Early Childhood. Education Administration Makassar State University majoring in early childhood education. 2018

Izza EN. Influence of Storytelling Method Against Child Development Emotional Intelligence Group B Kindergarten Dharma Wanita Kedung Gempol. Teacher Education Program Early Childhood Education Faculty of Education, State University of Surabaya. 2013

Jumiyati. Methods of Use Stories For Investment Advice On Moral Values in Early Childhood Education Early 
Childhood Gajahwong, Timoho, Yogyakarta. Universtitas Yogyakarta State. 2015

Munawaroh K. Coarse Motor Skills Improvement Through Dance Animal Dance Event on Children in Kindergarten ABA Group A Asem Lice Yogyakarta. Yogyakarta State University. 2015

Ning E. Methods of Use Playing Peeran In Language Skills to Grow Early Childhood. Journal Empowerment. 2013

Gymnastics Event Pujiastuti Fantasy N. Influence on Children Kinesthetic Intelligence Group B at Kindergarten Pertiwi $01 \quad$ Girilayu Matesih Karanganyar 2016/2017 Academic Year. Study Program Early Childhood Education Faculty of Teacher Training and Education Muhammadiyah University of Surakarta. 2017

Rahmawati, et al. Morning gymnastics to Build Student Motivation Tunagrahita. Journal Ortopedagodia. 2018

Sari, et al. Fantasy Gymnastics Motor Ability Against Abusive Autistic children in SDN Inclusion. Special Education Faculty of Education, State University of Surabaya. 2016
Sugiyono. Statistics For Research. Bandung: Alfabeta. 2016

Sujiono, et al. Method of Physical Development. South Tangerang: the Open University. 2016

Sulastri. Influence Use of the Media Audio Motion Lagu Anak Ceria (GELARIA) Motor Ability Against Abusive Kindergarten Pedagogia. Department of Educational Technology State University of Yogyakarta. 2017 EJournal of Educational Technology Vol Prodi, VI Number 7

Yenny. Motor Childhood Development Overview 5-6 Years Play Games Gadgets. $X$ Scientific Meeting Proceedings Developmental Psychology Association of Indonesia. 2017

Yusmarni. Upgrades Rugged Motor Gymnastics Kids Through Fantasy According to the story in Kindergarten State Trustees Padang Pariaman. The charm of early childhood 2012. Volume I No. 1. 